\title{
PENGARUH SISTEM PERKAWINAN ISLAM TERHADAP SISTEM HUKUM PERKAWINAN MASYARAKAT
}

\author{
Hj. Sugiatminigsil *
}

\begin{abstract}
Abstrak
Hukum perkawinan Islam sebelum disyahkan sebagai Undang-undang Perkawinan, sebenarnya norma yang berhubungan dengan sistem perkawinan (tata cara perkawinan) secara Islam telah lama berlaku dalam masyarakat Islam, bahkan sejak pertama kali agama Islam masuk dan membentuk konunitas Islan.

Pancasila dasar negara Indonesia, dan sebagian besar penduduk Indonesia beragama Islam, maka dalam rangka pembinaan Hukum Nasional, hikum Islam mempunyai peluang yang sangat besar untuk masuk sebagai salah satu bahan pokok yang sangat diperlukan dalam pemibinaan hukum Nasional tersebut.
\end{abstract}

Kata kunci: Perkawinan, Masyarakat, Hukum, Kompilasi.

\section{A. Pendahuluan}

Perkawinan merupakan suatu peristiwa yang suci dan mulia sebagai sunnah Rasulullah SAW yang dinyatakan dalam salah satu haditsnya yaitu: "An-nikaahu sunnatii, faman roghiba 'an sunnatii falaisa minnii" Al-Hadits.

Artinya: Nikah itu adalah sunnahku (Nabi), barang siapa meninggalkan sunnahku, maka mereka bukanlah termasuk golonganku (Nabi Muhammad SAW).

Dalam hadits di atas adalah merupakan anjuran yang seharusnya dilaksanakan bagi segenap insan yang telah memenuhi kriteria perkawinan tersebut. Pengaruh sistem perkawinan di sini difokuskan dalam masyarakat Islam, oleh karena mayoritas penduduḱ Indonesia beragamia Islam. dalan memahami hukum dan masyarakat adanya perbedaan sebagai berikut.

Pembedaan dan pemilahan konseptual yang dualistik antara apa yang harus disebut hukum dan apa yang harus disebut masyarakat itu sebenamya bukannya terjadi karena proses-proses tanpa sebab. Ide yang membedakan analitik antara hukum dan masyarakat berkonsidensi dengan pembedaan antara "Negara" dan "Masyarakat Sipil", itu erat hubungannya dengan perubahan-perubahan kondisikondisi sosial politik yang terjadi di Eropa'Barat. 
Tumbuh kembangnya negara-negara nasional berteritori di bagian benua ini, tempat para pakar yang nama-namanya disebut-sebut oleh para cendekiawan berefleksi dan mengambangkan konsep yang dasar legitimasinya tak lagi dipandang cukup kàlau cuma ditumpukan pada asas-asas moral religius yang implisit atau institusi sosial yang informal. Maka terjadilah di sini nasionalisasi, positivisasi, formalisasi, dan (pendek kata) politisasi sistem hukum, yang secara analitik lalu bisa dibedakan dari tertib masyarakat.

Sejalan dengan terjadinya pemisahan dan pengolahan konseptual antara law atau state yang supra dan civil society' yang intra telah memungkinkan kajian tentang hubungan antara hukum dan masyarakat; dan juga tentang kemungkinan menggarap hukum dan masyarakat masing-masing sebagai variabel empirik yang berfungsi di dalam suatu konteks atau ajang-ajang tempat bekerjanya berbagai kekuatan sosial dan makro.

Dengan tujuan pemahaman hukum dan masyarakat sebagai variabel-variabel yang tak lagi bersifat moral melainkan sekunder, relatif dan temporal seperti itulah kajian-kajian sosiologi hukum yang mengungkapkan dan menggarap hukum dan masyarakat masing-masing sebagai entitas yang dependen dan interdependen, mulai marak.

Diemansipasikan dan dilepas dari tambahan emparative moralnya, hukum dan masyarakat dapatlah dikaji bersaranakan metode-metode saintifik guna menemukan simpulan-simpulan tentang benar salahnya (legal) judgements.

Di atas dasar konseptual dan metodologik seperti itulah perintis-perintis kajian hukum dalam konsepnya sebagai variabel sosial (pada tataran analisisnya yang makro) mulai dirintiskan orang, empat di antaranya, yang namanya amat populer dan dikenal sampai kini adalah Karl Marx, Henry S., Maine, Emille Durkheim, dan Max Weber. Variasi pemikiran mereka berempat itu berikut kekhususan-kekhususan sumbangan pemikiran mereka dalam persoalan hukum dan masyarakat.

Sebagaimana diketahui bahwa setiap masyarakat selalu memiliki pranata sosial berupa nilai dan norma yang harus ditaati oleh setiap anggota masyarakat tersebut. Apabila seseorang anggota masyarakat tidak menata pranata sosial yang berlaku di dalam kehidupan sosial masyarakat itu, maka dia mendapatkan sanksi dari masyarakat itu. Dalam hal ini terjadilah pengendalian sosial terhadap perilaku individu tersebut. Menurut Berger (1978:83-84) pêngendalian sosial didefinisikan sebagai "various means used by a society to bring recalcitrat members back to line". Dalam definisi ini berarti bahwa pengendalian sosial adalah cara yang digunakan masyarakat untuk menerbitkan setiap anggotanya yang membangkang. Lebih rinci Roucek (1965:3) menjelaskan bahwa pengendalian sosial adalah:

"a collective term for those process, planned to the ussages and lifevalues of group". Definisi yang diberikan oleh Roucek ini jauh lebih luas, yaitu bahwa pengendalian sosial bukan terbatas hanya pada tindakan untuk mengontrol 
terhadap mereka membangkang, tetapi juga mencakup pula bagaimana proses sosialisasi dari nilai dan norma terhadap setiap anggota masyarakat, sehingga mereka bisa hidup menyesuaikan diri pada nilai norma tersebut.

Berbagai macam cara yang dilakukan oleh masyarakat dalam rangka mengendalikan anggota, misalnya: membujuk, mengolok-olok, mendesas-desuskan, mempermalukan dan bahkan mengucilkan. Berger (1978:9) menjelaskan lebih lanjut bahwa masing-masing di antara kita tentu akan mengalami bahwa setiap perilaku kita dikendalikan oleh suatu sistem pengendalian sosial yang berlaku dalam kehidupan lingkungan tetangga kita. Seorang anak yang belum pulang sampai larut malam, misalnya pasti akan ditegur oleh orang tuanya atau bisa jadi akan dimarahi oleh mereka. Begitu juga seorang murid yang berambut gondrong, pasti akan ditegur oleh gurunya.

Oleh sebab itu, tidak mengherankan bahwa salah satu obyek kajian dari Sosiologi Hukum adalah berlakunya nilai dan norma, sosialisasinya serta bagaimana mekanisme pengendalian sosial dalam kehidupan bermasyarakat. Dalam hal ini "hukum" adalah norma positif, yaitu suatu kaidah atau norma sosial yang ditegaskan sebagai hukum, dalam bentuk perundang-undangan. Lebih lanjut "hukum" merupakan dasar pembenar yang dibenarkan untuk dirujuk oleh para penguasa pemerintahan ketika mereka bekerja untuk mengendalikan perilaku warga masyarakat. Tujuannya adalah agar keteraturan dalam kehidupan bermasyarakat bisa terwujud. Itulah sebabnya Donald Black. dalam bukunya the Behavior of Law mendefinisikan bahwa hukum adalah government social control (Wignyosoebroto, 2003:2).

Sehubungan dengan hal itu, maka sebelum hukum perkawinan Islam disyahkan sebagai Undang-undang Perkawinan, sebenarnya norma yang berhubungan dengan tata cara perkawinan secara Islami telah lama berlaku dalam masyarakat Islam, yaitu sejak agama Islam pertama kali masuk dan membentuk komunitas Islam. Walaupun Indonesia bukan suatu negara Islam, namun mengingat bahwa sebagian besar penduduk Indonesia beragama Islam dan juga Pancasila menjadi dasar Negara, maka dalam rangka pembinaan Hukum Nasional, hukum Islam mempunyai peluang yang sangat besar untuk masuk sebagai salah satu bahan pokok yang sangat diperlukan untuk membina hukum nasional tersebut (Seakan, 1997:10).

Berbicara tentang sistem hukum perkawinan Islam pada dasarnya adalah membicarakan salah satu aspek dari hukum Islam di Indonesia, kita akan memasuki sebuah perbincangan yang kompleks sekalipun Hukum Islam menempati posisi yang sangat penting dalam kehidupan berbangsa dan beınegara pada masa sekarang. Persoalan dikatakan bersifat sangat kompleks adalah karena:

(:I)Berlakunya Hukum Islam di Indonesia untuk sebagian besar adalah tergantung pada umat Islain yang menjadi pendukung utamanya. Umat dalam artian sebuah komunitas penganut suatu agama yang dituntut melaksanakan kewajiban 
-ajaran dengan kekuasaan terutama sekali kekuasaan Negara. Indonesia bukanlah sebuah Negara Islam tetapi sebuah Negara Nasional yang tidak memberi tempat pada umat-Is̀lam untuk melaksanakan Hukum Islam tetapi juga pada umat-umat penganut agäma lain dalam hal ini Kristen Protestan, Katholik, Hindu dan Budha. Akan tetapi, secara formal negara juga tidak sepenuhnya menutup mata dari pelaksanaan hukum Islam sebagai berikut di samping punya landasan dogmatik pada ajaran agama, keberadaan hukum Islam juga didukung oleh umatnya dan untuk sebagian mempunyai landasan formal dari kekuasaan Negara Republik Indonesia.

(2)Sekalipun Hukum Islam sudah dilaksanakan di Indonesia dalam kehidupan umatnya sudah lebih dari ribuan tahun namun Hukum Islam Indonesia belum memperlihatkan bentuknya yang utuh sesuai dengan konsep dasarnya menurut AlQur' an dan Sunnah. Kenyataan ini adalah merupakan sebuah refleksi berlangsungnya proses Islamisasi yang.berlanjut terus dalam kehidupan umat Islam yang kelihatannya masih belum mencapai titik final. Sejak dulu sudah disadari bahwa masih banyak dari kalangan umat Islam yang menunjukkan komitmen yang menyeluruh dan utuh terdapat Hukum Islam karena masih menunjukkan sikap mendua dimana pada satu pihak ia menyatakan sebagai seorang penganut agama Islam sedangkan pada lain pihak ia masih belum melaksanakan hukum Islam secara menyeluruh. Ada beberapa faktor kehidupannya ia masih berkiprah pada ketentuan hukum adat yang dalam banyak hal kurang selaras dengan hukum Islam.

(3)Hukum Islam dengan daya lenturnya (adabtability)-nya yang tinggi senantiasa berpacu dengan perkembangan kemajuan zaman. Akan tetapi, usaha untuk selalu mengaktualkan Hukum Islam untuk menjawab perkembangan dan kemajuan zaman masih belum dikembangkan sebagaimana mestinya, bahkan cenderung hanyut dalam pertentangan yang tak kunjung selesai sehingga untuk beberapa abad kita masih belum menunjukkan karya nyata mengenai hal ini (Abdurrahman, 1995:3).

\section{B. Sejarah Masuknya Islam Dan Undang-Undang Yang Berlaku}

Sebagaimana diketahui bahwa Islam telah masuk ke Indonesia sejak abad pertama hijriah atau abad ketujuh atau kedelapan masehi. Daerah yang pertama didatanginya adalah pesisir utara Pulau Sumatra dengan pembentukan masyarakat Islam pertama di Peurelak Aceh Timur dan kerajaan Islam pertama di Samudera Pasai, Aceh Utara (Ali, 1993:209).

Sejak saat itulah sebenarnya sistem Hukum Islam telah berlaku pada masyarakat di kerajaan Islam pertama. Kerajaan-kerajaan Islam yang kemudian berdiri, melaksanakan Hukum Islam dalam wilayah kekuașaannya masing-masing: Setelah Samudera Pasai, berdirilah kemudian kerajaan Demak, Jepara, Tuban, Gresik dan beberapa kerajaan lainnya di luar Jawa. Namun demikian karena 
perbedaan letak geografis dan juga perbedaan penafsiran ulama lokal, maka sistem hukum Islam yang berlaku juga berbeda-beda (Koesnoe, 1982:2).

Menurut Arifin (1985:27), pemerintah Indonesia menemukan bahwa hukum Islam yang berlaku tidak tertulis dan terserak di berbagai macam kitab yang sering berbeda tentang hal yang. sama antara satu dengan lainnya. Biasanya ditemukan bahwa dalam setiap masalah selalu memiliki aspek hukum yang berbeda karena berbagai macam pendapat (Qaul) yang berbeda pula. Oleh sebab itu masing-masing individu atau kelompok yang sedang berpekara biasanya menggunakan argumen hukum yang berbeda sesuai dengan paham atau aliran dalam fiqh masing-masing. Apabila terdapat pemahaman bahwa perbedaan pendapat di antara para Fuqaha adalah rahmat. Masalahnya adalah bagaimana suatu pengadilan akan mengambil keputusan, kalau suatu peraturan belum jelas dan sama bagi semua orang, atau dalam istilah lain belum adanya kepastian hukum.

Oleh sebab itu, Undang-undang No. 22 Tahun 1946 dan Undang-undang Nomor 32 Tahun 1945 dimaksudkan untuk memenuhi kebutuhan mendesak akan adanya kesatuan dan kepastian hukum dalam pencatatan nikah, talak dan rujuk umat Islam yang sebelumnya masih diatur oleh beberapa peraturan yang bersifat propensialistis dan tidak sesuai dengan negara Republik Indonesia sebagai negara Kesatuan. Peraturan-peraturan tersebut ialah Huwellijksordonnatie S. 1929

No. 348 jo S. 1933 No. 98 san Huwerllijksordonnatie Buitengeswesten S. 1932 No. 482.

\section{Pengaruh Budaya Dan Mazhab}

Dalam Islam budaya dan perubahan sosial itu sangat jelas pengaruhnya terhadap pemikiran hukum. Perbedaan budaya dan perubahan sosial yang terjadi di daerah-daerah yang dikuasai oleh umat Islam di awal abad ke-2 Hijriyah sampai pertengahan abad ke-4 Hijriyah merupakan salah satu faktor yang menyebabkan terjadinya perbedaan-perbedaan pendapat di kalangan fuqaha (ulaman fiqih) mengenai sesuatu masalah hukum yang akhirnya menyebabkan terbentuknya aliranaliran hukum dalam Islam.

Lahirlah mazhab-mazhab (aliran) dalam mendefinisikan dan menetapkan hukum Islam, misalnya mazhab Hanafi dipelopori oleh Imam Abu Hanifah

An-Nu'man bin Tsabit di Kufah Irak, mazhab Maliki yang dipelopori oleh Malik bin Anas di Medinah. Sedangkan mazhabSyafi'i dipelopori oleh Muhammad bin Idris di Bagdad, kemudian pindah ke Mesir (pendapat Syafi'i sendiri sewaktu menetáp di Mesir, karena berbedanya budaya masyarakat kedua negara itu). Sedangkan mazhab Hambali dipelopori oleh Ahmad bin Hambal di Bagdad.

Itulah sebabnya budaya mempunyai tempat pembahasan khusus dalam hukum Islam, yakni pada 'urf (adat kebiasaan). Adat kebiasaan tersebut dijadikan salah satu metode penetapan hukum Islam. Hal ini disebabkan tujuan hukum itu adalah 
untuk mewujudkan ketertiban dan keadilan dalam masyarakat. Oleh sebab itu, apabila suatu masyarakat sudah memiliki norma hukum kebiasaan yang baik serta mewujudkan ketertiban dan keadilan sosial, makahukum itu dikukuhkan berlakunya oleh Islam. Demikian juga sebaliknya, apabila kebiasaan yang tidak sesuai dengan rasa keadilan, maka ketidakadilan itulah yang ingin direvisi oleh Islam dan kemudian Islam tidak hanya membawa hukum-hukum baru yang mengatur segala segi hubungan sesama manusia dalam kehidupan sosialnya, tetapi juga berusaha mengukuhkan hukum-hukum yang telah dianut oleh masyarakat sebelum datangnya Islam, apabila hukum-hukum itu tidak secara jelas bertentangan dengan prinsip hukum Islam. Suatu contoh, misalnya "jika seseorang penjahit disuruh menjahitkan pakaian, maka benang dan jarum adalah tanggungannya. Atau jika seseorang bapak menyerahkan anaknya kepada seorang pengrajin untuk diajarkan bertukang dengan tanpa syarat tentang upah di antara keduanya, maka jika setelah pengajaran anak itu selesai dan salah seorang menuntut upah, maka ketentuan hukum yang harus berlaku adalah kebiasaan yang ada di negeri yang bersangkutan. Jika menurut kebiasaan di situ sang guru (pengrajin) yang harus memberi upah, maka ia wajib memberikannya kepada anak itu, dan begitu juga sebaliknya".

Sebuah contoh mengenai perubahan hukum Islam karena perubahan sosial ialah ketentuan zakat kuda. Pada zaman Rasulullah, kuda tidak wajib dizakati, tetapi pada masa Umar bin Ibnu Khatab kuda wajib dizakati, apabila sudah mencapai nisabnya (ukurannya). Hal ini disebabkan di masa Umar, kuda itu mulai diternakkan dan diperdagangkan, sedang pada masa Rasulullah tidak demikian, Jadi hal ini berarti bahwa ketepatan hukum dapat berubah seiring dengan perubahan sosial, dalam hal ini kehidupan ekonomi masyarakat yang makin berkembang saat ini. Kedua contoh tersebut menunjukkan adanya pengaruh kebiasaan atau budaya masyarakat dan perubahan sosial terhadap perkembangan hukum Islam. Ini disebabkan karena hukum itu tidak dapat terlepas dari perubahan sosial. Hukum itu akan tumbuh dan berkembang sesuai dengan tingkat kemajuan masyarakat. Disinilah letak tugas hukum itu, yaitu memberi arah kepada perubahan dan menertibkan kepincangankepincangan sosial yang terjadi akibat pelaksanaan pembangunan (Tebba, 2003:4).

\section{Sistem Perkawinan Islam}

Dalam hal ini negara Indonesia, sebagaimana tertuang dalam pembukaan Undang-undang Dasar 1945 tersirat pada alinea keempat dengan mencantumkan dasar negara Pancasila, Bhineka Tunggal Eka. Beraneka ragam pandangan dan agamanya serta suku bangsanya tapi tetap satu kesatuan adanya saling hormat menghormati, antara masyarakat yang satu terhadap masyarakat lain, sistem hukum yang satu dengan sistem hukum yang lain.

Di negara kita Indonesia ini, sistem perkawinan yang diatur dalam Undang- 
undan'g Nomor 1 Tahun 1974 (Undang-undang No. 1 Tahun 1974) Undang-undang tentan'g perkawinan. Dalain hal ini sebelum adanya kompilasi hukum Islam, maka bagi masyarakat Islam yang berada di Jawa dan di Pulau Madura dalam hal kasus perkawinan (nikah, talak dan rujuknya) juga tentang waris dalam putusan hakim berbeda antara pengadilan agama di Jawa dan pengadilan agama di Madura. Juga bagi masyarakat yang tidak menganut agama Islam, maka bagi mereka berlaku di catatan sipil dalam melaksanakan perkawinan mereka.

Hal ini menunjukkan bahwa badan peradilan mengenal fiderensi di samping spesialisasi. Demikian pula dalam sistem perkawinan, sebagaimana diatur dalam Undang-undang Nomor 1 Tahun 1974 tentang Perkawinan, mengenal diferensiasi karena perbedaan agama dan kepercayaan. Dengan demikian, dilihat dari aspek kemajemukan masyarakat bangsa, sebagian hukum yang berlaku dalam sistem hukum nasional bersifat majemuk (pluralistic), ia mengenal berbagai golongan masyarakat yang masing-masing tunduk kepada hukum yang berlainan, khususnya dalam hukum keperdataan.

Kemungkinan dalam tatanan hukum itu sangat menonjol dalam hukum keluarga, yaitu semua kaidah hukum yang mengatur hubungan abadi antara dua orang yang berlainan jenis kelamin serta akibat-akibatnya, meliputi hukum perkawinan dan hukum kewarisan (CF. Sudirman K., 1955:57). Kemajemukan itu mengacu kepada sistem sosial (struktur dan kebudayaan) yang dianut oleh masing-masing "golongan", sebagai bagian dari suatu sistem masyarakat bangsa secara keseluruhan. Hal itu memungkinkan bahwa sistem hukum merupakan salah satu unsur dalam sistem masyarakat secara makro yang terkait dengan nilai-nilai yang dianut oleh masyarakat yang bersangkutan.

Peradilan agama yang diperuntukkan bagi mereka secara nyata sudah ada dan tersebar di berbagai daerah di Indonesia, dengan beraneka ragam sebutan namanya, seperti Rapat Ulama, Raad Agama, Mahkamah Islam, Mahkamah Syura', Priesterraad, Pengadilan Paderi, Godstdientigerechtspraak, Godsdientst Beamte, Mohammadencesche Godsdienst Beamte, Kerapatan Qadli, Hof voor Islamietische Zaken, Kerapat Qadli Besar, Mahkamah Islam Tinggi dan sebagainya.

Pada zaman Jepang tidak banyak mengalami perubahan, tetapi pada tahun 1857 yakni setelah Indonesia merdeka ada lagi Badan Peradilan Agama yang dibentuk baru dengan sebutan Pengadilan Agama atau Mahkamah Syari'iyah dan Pengadilan Agama atau Mahkamah Syari'iyah Propinsi. Sampai dengan awal tahun 1980, nama Badan Peradilan Agama itu terdiri dari tiga kelompok, yaitu:

1. Kelompok Peradilan di Pulau Jawa Madura (Stbl., 1882 No. 152 jo 1937 No. 116 dan 610) disebut Pengadilan Agama (terjemahan dari Preisterraat) dan Mahkamah Islam Tinggi (terjemahan dari Hof voor Islammietische Zaken). 
2. Kelompok Peradilan Agama di sebagian daerah Kalimantan Selatan dan Timur (Stbl. 1937 No. 638 dan 639) disebut dengan Kerapatan Qadli (terjemahan dari Kadigerecht) dan Kerapatan Qadli Besar (terjemahan dari Oper Kadigerecht).

3. Kelompok Peradilan agama selain dari satu atau di atas (PP No. 45 Tahun 1957)' disebut Peradilan Agama atau Mahkamah Syari' iyah dan Pengadilan Agama atau Mahkamah Syari'iyah Propinsi.

Sebutan yang aneka ragam itu dengan Keputusan Menteri Agama Nomor 6 Tahun 1980 tanggal 28 Januari 1980 diseragamkan menjadi Pengadilan Agama (atau tingkat pertama) dan Pengadilan Tinggi Agama (untuk tingkat banding), tetapi tidak menseragamkan kompetensinya, sebab Keputusan Menteri tidak cukup kuat untuk mengubah kompetensinya. Peradilan Agama yang dulunya diatur dengan Ordonantie atau Peraturan Pemerintah. Sebutan seragam ini nantinya diambil over ke dalam Undang-undang Nomor 7 Tahun 1989 (Rasyid, 1995:17).

Meskipun Pemerintah Hindia Belanda pada tahun 1937 mengeluarkan bidang Kewarisan dan kewenangan Pengadilan Agama di Jawa dan Madura dengan dikeluarkan Stbl. 1937 No. 116, namun de facto Hukum Islam masih tetap menjadi pilihanuntuk menyelesaikan masalah kewarisan di antara mereka melalui Pengadilan Agama.

Namun demikian terjaminnya kedudukan Hukum Islam dalam Negara Republik Indonesia sebagai negara hukum berdasarkan Pancasila dan UUD 1945 tidaklah otomatis memberikan bentuk hukum Islam sebagaimana hukum tertulis.

Pemerintah Republik Indonesia menemukan kenyataan bahwa hukum Islam yang berlaku itu tidak tertulis dan terserak di berbagai Kitab yang sering berbeda tentang hal yang sama antara satu dengan lainnya. Hal tersebut bersesuaian dengan pendapat beberapa orang Hakim Agung yang mengemukakan beberapa seginya secara lebih rinci lagi. Bustanul Arifin misalnya mempersoalkan tentang adanya masalah hukum Islam yang diterapkan oleh Pengadilan Agama. Dikatakannya bahwa Hukum Islam (Fiqh) tersebar dalam sejumlah besar kitab susunan para Fuqaha beberapa abad yang lalu. Biasanya dikatakan bahwa dalam setiap masalah selalu ditemukan lebih dari satu pendapat (Qaul). Wajar jika orang bertanya."Hukum Islam yang mana?" bagi pribadi-pribadi atau kelompok-kelompok tertentu mungkin telah jelas mengingat masing-masing telah menganut paham tertentu. Hal ini menurut pendapatnya adalah suatu kenyataan yang tidak bermaksud mengingkari bahwa perbedaan pendapat di antara para Fuqaha adalah rahmat, akan tetapi yang ditekankan di sini adalah bahwa untuk diberlakukan di Pengadilan, suatu peraturan harus jelas dan sama bagi semua orang, yakni harus ada kepastian hukum (Arifin, 1985:27).

Undang-undang Nomor 22 Tahun 1946 dan Undang-undang Nomor 32 Tahun 
1954 dimaksudkan untuk memenuhi kebutuhan mendesak akan adanyä kesatuan dan kepastian hukum dalam pençatatan nikah, talak dan rujuk umat Islam yang masih diatur oleh beberapa peraturan yang bersifat propensialistis dan tidak sesuai dengan negara Republik Indonesia sebagai negara kesatuan. Adapun tentang peraturannya yang dimaksud telah disebutkan pada pernbahasan sebelumnya.

Pada saat itu juga telah menjadi pergeseran beberapa bagian hukum Islam ke arah tertulis dan termuat dalam beberapa bagian penjelasan Undang-undang Nomor 22 Tahun 1946. Dijelaskan pula bahwa pada saat itu Hukum Perkawinan, Talak dan Rujuk (umat Islam) sedangkan dikerjakan oleh Penyidik Hukum Perkawinan, Talak dan Rujuk yang dipimpin oleh Mr. Teuku Mohammad Hasan.

Hal demikian sejalan dengan dikeluarkannya Edaran Biro Peradilan Agana No. B/1/735 tanggal 18 Februari 1958 sebagai pelaksanaan PP. 45 Tahun 1957 tentang Pembentukan Pengadilan Agama/Mahkamah Syar'iyah di luar Jawa dan Madura. Kemudian makin berkembang dengan melalui berbagia macam proses yang ditempuh.

Dalam rangka mencapai keseragaman tindak antara Mahkamah Agung dan Departemen Agama dalam pembinaan Badan Peradilan sebagai satu langkah menuju terlaksananya Undang-Undang No.14 Tahun 1970 tentang Ketentuanketentuan Pokok Kekuasaan Kehakiman serta untuk menghindari perbedaan penafsiran dalam melaksanakan Undang-Undang No.1 Tahun 1974, pada tanggal 16 September 1976 telah dibentuk Panitia Kerjasama dengan Surat Keputusan Ketua Mahkamah Agung No.04/KMA/1976 yang disebut PANKER MAHAGAM (Panitia Kerjasama Mahkamah Agung/Departemen Agama) (PTA. Jatim, 1995:131).

Setelah adanya kerjasama dengan Mahkamah Agung, maka kegiatan Departemen Agama dalam mewujudkan kesatuan hukum dan dibentuk hukum tertulis bagi hukum Islam yang sudah berlaku dalam masyarakat yang sebagian masih sebagai hukum tidak tertulis, menampilkan diri dalam rangkaian seminar, simposium dan lokakarya serta penyusunan Kompilasi Hukum Islam bidang hukum tertentu, antara lain:

1. Penyusunan Buku Himpunan dan Putusan Peradilan Agama tahun 1976;

2. Lokakarya tentang Pengacara pada Pengadilan Agama tahun 1977;

3. Seminar tentang Hukum Waris Islam tahun 1978;

4. Seminar tentang Pelaksanaan UU Perkawinan tahun 1979;

5: Simposium beberapa Bidang Hukum. Islam tahun 1982;

6. Simposium Sejarah Peradilan Agama tahun 1982:

7. Penyusunan Himpunan Nash dan Hujjah Syar'iyah tahun 1983;

8. Penyusunan Kompilasi Peraturan Perudang-undangan Peradilan Agama tahun 1981;

9. Penyusunan Kompilasi Hukum Acara Peradilan Agama I tahun 1984; 
10. Penyusunan Kompilasi Acara Peradilan Agama II tahun 1985;

11. Penyusunan Kompilasi Hukum Acara Peradilan Agama III tahun 1986;

12. Penyusunan Kompilasi Hukum NTCR I dan I tahun 1985.

Dalain:kegiatan tersebut telah diikutsertakan ahli hukum dari beberapa kalangan hukum terkait seperti Hakim, Pengacara, Notaris, Kalangan Perguruan Tinggi, Departemen. Kehakiman, IAIN dan juga tokoh-tokoh masyarakat, Ulama dan Cendekiawan Muslim serta perorangan lainnya.

Sementara itu pertemuan antara Ketua Mahakamah Agung RI dengan Menteri Agama RI tanggal 15 Mei 1979 menghasilkan disepakatinya penunjukan enam orang Hakim. Agung dari Hakim Agung yang ada untuk bertugas menyidangkan dan menyelesaikan permohonan kasasi yang berdasarkan dari lingkungan Peradilan agama (PTA. Jatim, 1995-131).

Periode ini dimulai sejak ditandatanganinya Surat Keputusan Bersama Ketua Mahkamah Agung dari Menteri Agama RI tentang Penunjukan pelaksana Proyek Pembangunan Hukum Islam melalui Yurisprudensi atau yang lebih dikenal sebagai Proyek Kompilasi Hukum Islam No. 07/KMA/1985 dan No. 25 Tahun 1985 tanggal 21 Maret 1985 di Yogyakarta, dikemukakan ada dua pertimbangan mengapa proyek ini diadakan, yaitu:

a. Bahwa sesuai dengan fungsi Mahkamah Agung Republik Indonesia terhadap jalannya peradilan disemua lingkungan peradilan di Indonesia khususnya di lingkungan Peradilan Agama, perlu mengadakan Kompilasi Hukum Islam yang selama ini menjadikan hukum positif di Pengadilan Agama.

b. Bahwa guna mencapai maksud tersebut, demi meningkatkan kelancaran pelaksanaan tugas, sinkronisasi dan tertib administrasi dalam proyek pembangunan hukum Islam melalui yurisprudensi, dipandang perlu membentuk suatu tim proyek yang susunannya terdiri dari para pejabat Mahkamah Agung dan Departemen Agama Republik Indonesia.

Bilamana kita perhatikan konsideran tersebut masih belum memberikan jawaban yang tegas mengenai mengapa kita harus membentuk kompilasi dimaksud. Bilamana kita teliti lebih lanjut ternyata pembentukan Kompilasi Hukum Islam ini mempunyai kaitan yang erat sekali dengan kondiși Hukum Islam selama ini. Hal ini, penting untuk ditegaskan mengingatkan seperti apa yang dikatakan oleh Muchtar Zarkasyi sampai saat ini belum ada suatu pengertian yang disepakati tentang Hukum Islam di Indonesia. Ada berbagai anggapan tentang Hukum Islam, yang masingmasing melihat dari sudut yang berbeda (Zarkasyi, 1985:3).

Di samping ketidaksamaan antara sudut pandang para ulama, Lawyer dalam putusan, juga dengan munculnya kehendak untuk menghapuskan hukum yang diwariskan oleh penjajah, bagi negara yang beru merdeka. Muncullah suatu 
pandangan untuk menyamakan pemberlakuan hukum di Jawa dan Madura sehingga muncullah suatu Komplikasi Hukum Islam yang terdiri dari tiga buku:

- $\quad$ Buku I (kesatu) tentang Perkawinan

- $\quad$ Buku II (kedua) tentang Kewarisan yang mencakup (hibah dan wasiat)

- $\quad$ Buku III (ketiga) tentang Perwakafan

Sedangkan menurut Pasal 10 UU No.14 Tahun 1970 itu tentang peradilan yaitu:

- Peradilan Agama

- Peradilan Militer

- Peradilan Tata Usaha Negara

Ketiganya merupakan peradilan khusus, karena mengadili perkara-perkara tertentu atau mengenai golongan masyarakat tertentu pula.

Sedangkan peradilan umum adalah peradilan bagi rakyat pada umumnya mengenai perkara perdata dan pidana. Perbedaan dalam empat lingkungan peradilan itu terbuka kemungkinan adanya pengkhususan (diferensi/spesialisasi) pada masingmasing lingkungan, misalnya dalam peradilan umum dapat diadakan pengkhususan berupa pengadilan lalu lintas, pengadilan anak-anak, pengadilan ekonomi dan sebagainya yang diatur oleh Undang-undang.

Hal itu menunjukkan bahwa badan peradilan mengenal differensiasi di samping spesialisasi.

Demikian pula dalam hukum perkawinan, sebagaimana diatur dalam Undangundang No.1 Tahun 1974 tentang Perkawinan.

Menurut Pasal 49 Undang-undang No.7 Tahun 1998 adalah hukum Islam mengenani perkawinan, kewarisan, hibah, wasiat, wakaf dan shadaqoh. Sumber hukum terapan tersebut adalah Undag-undang No.1 Tahun 1974 serta peraturan pelaksanaannya. Peraturan pemerintah No.28 Tahun 1977 dan hukum Islam tidak tertulis mengenai perkawinan, kewarisan, hibah wasiat, wakaf dan shadaqoh.

Berdasarkan INPRES No.1 Tahun 1991/jo Keputusan Menteri Agama No.154 Tahun 1991 juga dalam ketetapan MPR RI No.II/MPR/1993 tanggal 9 Maret 1993 bahwa:

Kedudukan peradilan agama dan peradilan negara sejajar, peradilan agama sebagai peradilan yang duduk sama rendah, berdiri sania tinggi, setara dengan peradilan lainnya dalam pelaksanaan tugas kekuasaan kehakiman di Indonesia. Hanya saja peradilan agama memutuskan perkara-perkara bagi masyarakat yang beragama Islam sedangkan peradilan umumnya juga perkara baik perdata maupun pidana bagi masyarakat umum.

Dengan adanya kompilasi hukum Islam itu pula yang mempunyai tujuan utama untuk keseragaman bagi lingkungan peradilan agama dan dijadikan pedoman oleh para hakim dalam melaksanakan tugasnya, sehingga terjamin adanya kesatuan 
dan kepastian hukum yang sama. Terhadap pengadilan agama di Jawa dan di Madura yang dulunya berbeda tentang putusan hakim dalam memperoleh kepastian hukum yang tetap. Namun sekarang, semenjak adanya pembentukan kompilasi Hukum Islam itu mäka sekarang menjadi sama.

Sebagai' akhir dari pembahasan tentang pengaruh sistem perkawinan terhadap sistem hukum perkawinan masyarakat Islam di Indonesia ini pada hakekatnya perlu diketahui sebelum di Undangkannya; Undang-undang No.1 Tahun 1974 tentang perkawinan tersebut, sebenarnya sistem perkawinan masyarakat Islam itu, telah berlaku dilaksanakan oleh masyarakat Islam sejak agama Islam masuk dan dianut di Indonesia, yang pada akhirnya diakui oleh pemerintah penjajah antara lain Belanda, Inggris dan sebagainya. Sehingga pengaruh sistem perkawinan sangat dominan pada sistem hukum perkawinan masyarakat Islam di Indonesia.

\section{E. Penutup}

Adanya suatu pembedaan dan pemilihan konseptual yang dualistik antara apa yang harus disebut hukum dan apa yang disebut dengan masyarakat, itu sebenamya bukannya terjadi karena proses-proses tanpa sebab.

Tumbuh kembangnya negara-negara nasional berteritori dibagian semua ini, tempat para pakar yang nama-namanya disebut-sebut oleh para cendekiawan berefleksi dan mengembangkan konsep yang dasar legitimasinya tak lagi dipandang cukup kalau cuma ditumpukan pada asas-asas moral religius yang implisit atau institusi sosial yang informal.

Maka terjadilah disini nasionalisasi, positivisasi, formalisasi dan (pendek kata) politisasi sistem hukum, yang secara analitik lalu bisa dibedakan dari tertib masyarakat. Sejalan dengan terjadinya pemisahan dan pemilahan konseptual antara law/state yang supra dan civil society yang infira telah memungkinkan kajian tentang hubungan antara hukum dan masyarakat, dan juga tentang kemungkinan meng garap hukum dan masyarakat masing-masing sebagai variabel empirik yang berfungsi didalam suatu konteks atau ajang-ajang tempat bekerjanya berbagai kekuatan sosial dan makro.

Dengan rujukan pemahaman hukum dan masyarakat sebagai variabel-variabel yang tak lagi bersifat moral normatif melainkan sekuler, relatif dan temporal seperti itulah kajian-kajian sosiologi hukum yang mengungkap dan menggaraphukum dan masyarakat masing-masing sebagai entitas yang dependen dan interdependen, mulai mara dari marak.

Berdasarkan INPRES I tahun 1991/jo Keputusan Menteri Agama Nomor 154 Tahun 1991 juga dalam Ketetapan MPR RI No. II/MPR/1993 tanggal 9 Maret 1993 bahwa:

Kedudukan peradilan agama dan peradilan negara sejajar, peradilan agmaa 
sebagai peradilan yang duduk sama rendah, berdiri sama tinggi, setara dengan peradilan lainnya dalam pelaksanaan tugas kekuasaan kehakiman di Indonesia. Hanya saja peradilan agama memutus perkara-perkara bagi masyarakat yang beragama Islam sedangkan peradilan umum juga perkara baik perdata maupun pidana bagi masyarakat unum.

Dengan adanya kompilasi hukum Islam itu pula yang mempunyai tujuan utama untuk keseragaman bagi lingkungan peradilan agama dan dijadikan pedoman oleh para hakim dalam melaksanakan tugasnya, sehingga terjamin adanya kesatuan dan kepastian hukum yang sama. Sehingga antara pengadilan agama di Jawa dan di Madura yang dulunya berbeda tentang putusan hakim dalam memperoleh kepastian hukum yang tetap, namun sekarang semenjak adanya pembentukan komplikasi hukum Islam itu maka sekararig menjadi sama.

\section{DAFTAR PUSTAKA}

Abdurachman, 1995. Kompilasi Hukum Islam, Akademika Pressindo, Jakarta. Ali, Muhammad Daud, 1993. Hukum Islam (Penganıar Ilmu Hukum dan Tatu Hukum Islam di Indonesia), Rajawali Pers, Jakarta.

Arifin, Bustanul, 1985. Pemahaman Hukum Islam dalam Kontekss Perundangundangan. Wahyu, No.108 Tahun VII Mei 1985.

Berger, Peter L., 1978. Invilaion to Sociology: A Humanistic: Perpective. Harmondsworth, Middlesex: Penguin Books. Diterjemahkan oleh Daniel Dhakidae dengan judul Humanisme Sosiologi. Jakarta: Penerbit Intisarana Aksara, 1985.

Hanafi Ahmad, MA, 1970. Pengantar dan Sejarah Hukum Islam, Bulan Bintang, Jakarta.

Khozim, 2001. Jejak-jejak Pendidikan Islam di Indonesia, Universitas Muhammadiyah Malang.

Koesnoe, Moh, 1982. Perbandingan antara Hukum Islam. Hukum Eropa dan Hukum Adaı. Prasaran Seminar, PTIS, Kaliurang.

Saekan \& Erniati Effendi, 1997. Komplikasi Hukum Islam di Indonesia. Arloka,

Surabaya. 
Siddik, Abdullah, 1980. Asas-asas Hukum Islam, Widjaya, Jakarta.

Tebba, Sudirman, 2003. Sosiologi Hukum Islam, UIl Pers, Yogyakarta.

Undang-Undang Perkawinan di Indonesia, Arloka, Surabaya.

Usman, Iskandar, 1991. Istilah Pembaharıan Hukum Islam, PT. Raja Grafindo Persada, Jakarta.

Wignjosoebroto, Soetanyo, 2003. Diktat Kuliah Sosiologi Hukum, Program Studi Magister Hukum, PPS-UNMER. 